\title{
Do Political Institutions Affect Housing Prices in Malaysia?
}

\author{
Noor Zahirah Mohd Sidek ${ }^{1}$ \\ ${ }^{1}$ Economics Department, Universiti Teknologi MARA (UiTM), Sungai Petani, Kedah, Malaysia \\ Correspondence: Noor Zahirah Mohd Sidek. E-mail: nzahirah@kedah.uitm.edu.my
}

Received: October 28, 2018

Accepted: November 9, $2018 \quad$ Online Published: November 29, 2018

doi:10.5539/ass.v14n12p134

URL: https://doi.org/10.5539/ass.v14n12p134

\begin{abstract}
This paper examines the relationship between housing price and political institutions. Political institutions is captured by elections, the role of elected government and their ramifications, and economic governance. Furthermore, the outcome of political choice on the economy is capture via economic freedom. Data ranges from 1988 to 2015. The choice of variable and time frame is highly restricted to availability of data. The effect of political institution on housing prices is examined using the ARDL bounds testing to test for both short and long run effects. Results show that elections have important effects on housing prices where prior to elections the effect is positive and negative after elections. Based on the results we recommend a strong and balance democratic regime to ensure a more stable housing prices. Strong political will is expected to curb excessive increase in housing prices in the long run.
\end{abstract}

Keywords: housing price index, institutions, political regime, economic freedom

\section{Introduction}

The erratic behavior of housing prices can no longer be explained by the traditional economic variable and are often difficult to predict (Manganelli, 2014; Rahadi et al., 2015). Housing price in Malaysia has been on a prolonged rising trend especially since 2010. Despite numerous economic slowdown in the form of financial crises and external shocks, the upward trend of housing prices in Malaysia is relatively unaffected (see Figure 1 and Figure 2). The continued increase in housing prices in Malaysia are commonly associated with several issues which can be categorized into three main areas. First, land issues. This include acquisition issues which increases the value of land, the lack of coordination in Land Act since the judiciary belongs to the state government rather than the Federal government, categorization, conditions and restrictions on land use and acquisition, land conservation, surrender and alienation and finally, geographical issues. Second is financing issues. Though financing is abundant, the requirements are quite stringent which prohibit young home buyers' especially low-income earners from owning houses. Third is developers' issues which centers on complicated procedures and bureaucracy which slows down completion and escalate costs. The bureaucracy and procedures include purchasing the land, land use conversion and sub-division, earthwork, building, engineering, construction and issuance of certificate of fitness prior to occupying the premise. These procedures are vital to ensure security and reliability of houses constructed but at the same time, various procedures results in longer approval time which increases the costs to developers. Finally, the 'affordability' issue which is tied to financing issues. There is an acute mismatch between the demand and supply of houses in Malaysia. While developers prefer to build medium to high-end housing, demand for housing comes from the bottom forty percent (B40) households and middle twenty percent households (M20), giving rise to the demand-supply mismatch. Several efforts have been undertaken by the government to provide more houses for B40 household but the demand for such houses still exceeds supply. To partly remedy these problems, the government has taken several initiatives to assist low income earners own homes via various intervention projects.

Given the issues discussed above, this paper intends to study housing prices from a different perspective. This paper examines the impact of political regime outcomes prior, during and post-elections, the role of the elected government and the ramification of choosing a particular party, on housing prices. As such, we contribute to existing literature by examining the impact of political institutions on housing prices.

This paper contributes to the existing body of knowledge in several manners. First, we attempt to assess the impact of political institutions on housing price. Malaysia provides an interesting case since it practices parliamentary democracy but the implementation is almost anarchic in nature. The existing government has ruled 
since independence with a relatively small number of oppositions as compared to other democratic countries worldwide. Second, we use a host of variables to test our proposition on how political institutions affect housing price. The impact of election, pre-election and post-election are thoroughly examined along with the outcomes of the elections. The choice of government which is later translated into economic policies were also examined using the economic freedom variables to capture the outcome of regime choice. Third, we test the relationship between housing price and political institutions over a more recent time frame from 1988 to 2015 which captures two crises period and major fluctuations in oil and food prices.

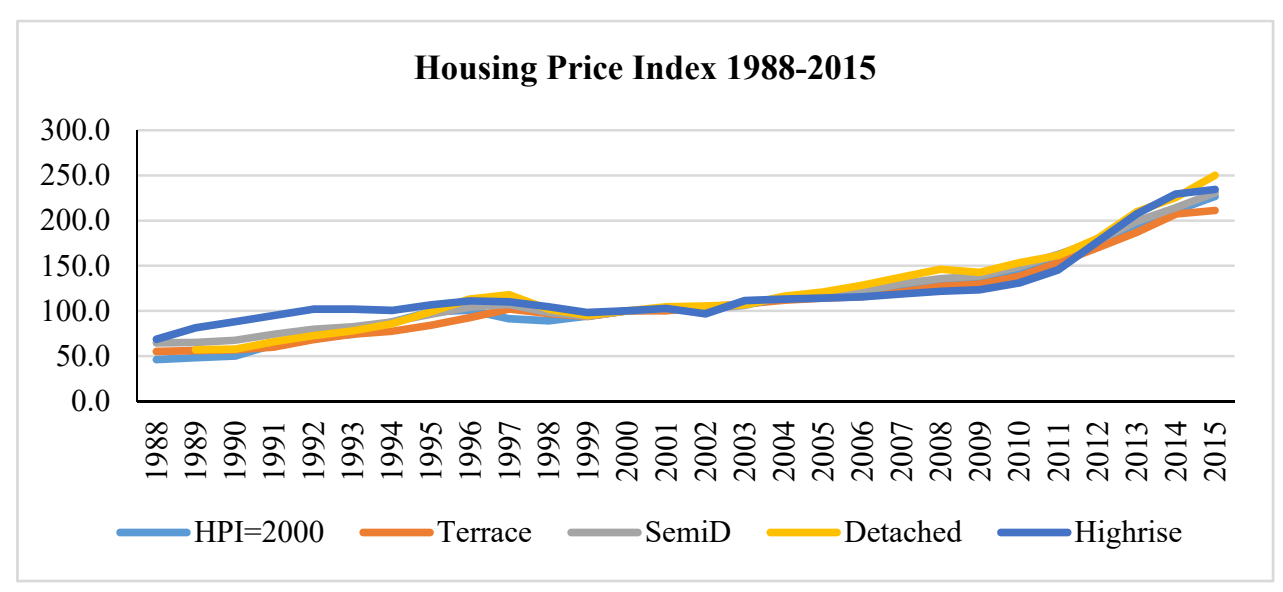

Figure 1. Housing Price Index 1988-2015

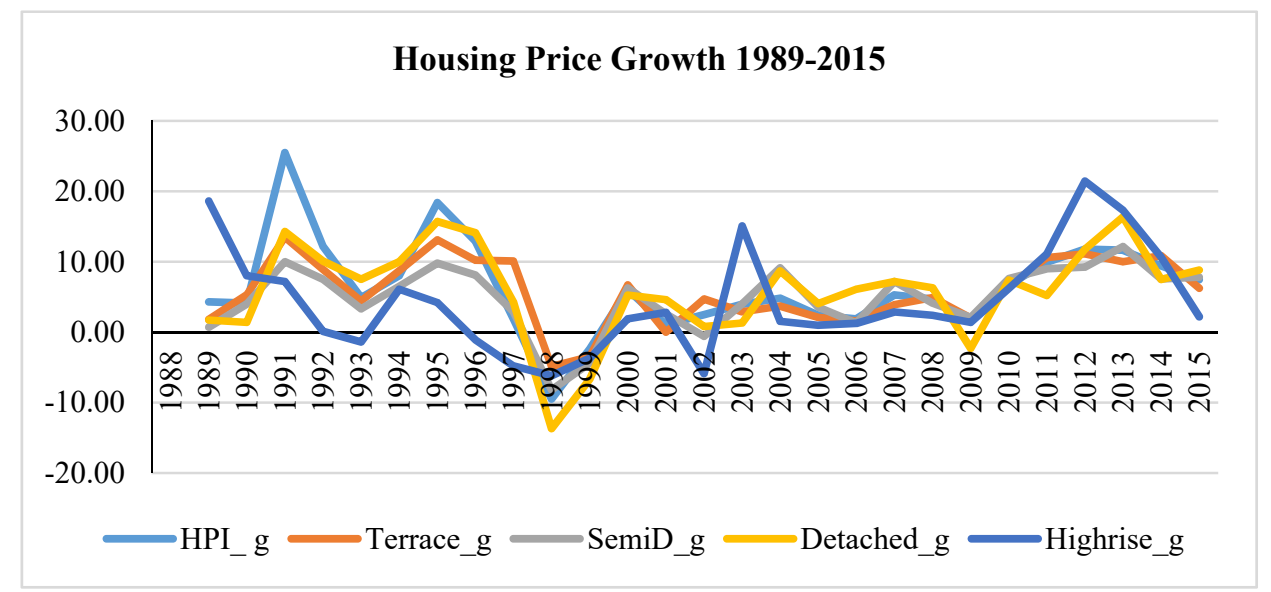

Source: NAPIC; Monthly Statistical Bulletin, Bank Negara Malaysia (various issues)

Figure 2. Housing Price Growth 1989-2015

The paper is organized as follows. The next section positions the paper within the current development of political economy theory and reviews existing literature. Section three discusses the choice of proxies for political institutions, how the proxies differ and what they intend to capture. This section also provides brief discussion on bounds testing technique and ARDL to test and estimate both short and long run relationships. The penultimate section discusses the results and some conclusions are drawn in the final section.

\section{Housing Price and Political Institutions: Review of Issues}

This section reviews on the literature on housing from the economic and institutional point of view. The first sub-section reviews how economic and financial factors affect housing prices followed by another sub-section on how political institutions affect asset prices and eventually, housing prices. The last sub-section delves into the housing scenario in Malaysia.

\subsection{Economic Impact on Housing Prices}

Ground breaking studies by Case (2000) and Catte et al. (2004) show how the traditional macroeconomic determinants affect housing prices in the US. Other more general studies such as Sutton (2002), Tsatsaronis and Zhu (2004), Terrones and Otrok (2004) examines macroeconomic effects on real estate prices.

Based on DiPasquale and Wheaton (1996), increase in economic activities will eventually increase house prices. 
Economic activities include higher GDP, higher industrial production or even increase in employment. An increase in industrial production for example, leads to higher demand for production space and since the supply of property stock could not increase immediately, higher demand is translated into higher rent which leads to higher property prices. Similarly, an increase in GDP or workers' income provide the ability to buy property for example houses but the supply for houses takes time to match the demand for houses resulting in higher rents in the short run which later leads to higher housing price in the long run (Adams and Fuss, 2010; Agnello \& Schuknecht, 2011; Hott \& Monnin, 2008; Oktay et al., 2014).

Credit supply is a major determinant of propensity to buy a house (Ciarlone, 2015; McCord et al., 2011; Pomogajko \& Voiglander, 2012). Acquiring a house takes up a large chunk of disposable income of an individual or household rendering the need for loans from either government or private (banks) sources. Whilst government housing loan is limited to government employees, private banks and other financing institutions are normally the best available option. The availability of credit for housing loan, duration of the loan and its lending rate are main factors for consideration prior to acquiring a property. In the case of Malaysia, maximum housing loan tenure is capped to 35 years only and house refinancing is capped at 10 years to ensure affordability of buyers' monthly installment (BNM, 2016) and to curb speculative activities in the property sector. From a different perspective, longer housing loan tenure means higher interest paid.

In relation with the availability of credit, the long-term interest rate affects the tendency to own a house. If the long run interest rate is higher, there is a tendency to switch investments from real estate to bonds or any other fixed income assets. Adams and Fuss (2010) note that higher interest rates for fixed housing loan can intensify capital switching which will adversely affect housing prices. Higher long run lending rates directly affects purchases of houses through higher mortgage rates (Goddard \& Marcum, 2012; Hott \& Monnin, 2008). On the other hand, higher mortgage rates may reduce the demand to purchase houses which, in the long run should lead to decrease in house prices. However, this is most unlikely since the price of houses are relatively sticky downward due to increasing costs of development and raw materials. From another perspective, lower real estate or housing prices deter more investments in construction leading to slower housing or real estate being developed. The short time interest rate affects housing prices in similar manner. Higher short-term interest rates reduce the demand for housing due to higher mortgage rates. In turn, higher mortgage rates translate to higher housing prices due to shortages in housing supply. Thus, the effect of both short and long-term interest rate on housing is ambiguous.

The next major determinant of housing prices is the costs of construction. Theoretically, higher construction costs increase the price of housing since the increase cost of housing development is passed to buyers (Gaspareniene et al., 2016). Sharp increase in housing price reduce the number of construction projects leading to lower housing stock. Consequently, lower housing stock suggests less housing space which pushes up rents. In the end, higher rents trigger higher housing price. Cost of input of construction industry in Malaysia has increased by 22.5 per cent per annum between 2012 to 2014 (Department of Statistics, 2014). On similar note, Real Estate and Housing Developers' Association Malaysia (REHDA) Property Industry survey has estimated around 20-25 per cent increase in the cost of imported construction materials as a result of weakening of the ringgit (The Sun Daily, 14 September 2015). Effective 14 April 2017, the government has imposed two safeguard measures to protect local steel industry. The new measures saw a 13.42 per cent for steel concrete reinforcing bar (REBAR) and 13.90 per cent import duty for steel wire rods (SWR) and deformed-bar-in-coil (DBIC) for the next three years (MITI, 2017). Labour wage rates have also increased over the years. For example, in 2012 a general construction worker earns around RM57 on average compared to a RM69 on 2016 on average (CIDB, 2012, 2016). These combined factors leads to higher construction costs. Theoretically, higher construction costs increase the price of housing since the increase cost of housing development is passed to buyers (Gaspareniene et al., 2016). Sharp increase in housing price reduce the number of construction projects leading to lower housing stock. Consequently, lower housing stock suggests less housing space which pushes up rents. In the end, higher rents trigger higher housing price.

Another branch of literature views macroeconomic shocks which come in the form of unexpected changes in money supply, interest rates, industrial production affect housing prices at rates determined by speed of propagation of such shocks. The lag(s) induced by the propagation of the shocks, on one hand, depends on government policies on land conversion and ownership, land availability, local government regulations, the pace of bureaucratic and administrative processes. Other traditional economic variable includes inflation, wage rate and population. A rise in inflation is expected to increase housing prices since the price of raw materials for example has risen and producers will pass the increase in costs of housing development to buyers via higher prices (Goddard \& Marcum, 2012; Zalieckaite et al., 2007). On contrary, deflation is expected to reduce house 
prices via the same mechanism. Employment which generates wages and salaries is expected to increase the purchasing power of potential house buyer as well as to provide for down payments since bank do not normally provide 100 per cent financing. Higher the wage rate or level of employment lead to rapid household disposable income growth which in turn, push up housing price (Oktay et al., 2014; Manganelli, 2014; Ahuja et al. 2010; Hua et al., 2012). Conversely, Tsatsronis \& Zhu, 2004; Lin et al., 2014; Ciarlone, 2015 argue that the availability of bank loans to finance house purchases has more significant impact compared to employment or wage rate. Finally, population growth has either negative or insignificant impact on housing prices (Mankiw \& Weil, 1989; Hort, 1998).

\subsection{Impact of Political Institution on Housing Prices}

The pivotal role of political institutions in financial and equity development has been widely studies. Empirical findings on the impact of political decisions on the asset market are often difficult to interpret due to notable absence of theoretical models. Pagano and Volpin (2001) study the political economy of finance in banking, securities market and corporate finance. Political institutions affect financial development in the form of rules and regulation (Haber et al., 2008) or legal institutions (La Porta et al., 1998; Qi et al., 2010; Bhattacharya \& Daouk, 2002; Hail \& Leuz, 2006; Boubakri et al., 2014). Legal institutions for example, influence the cost of capital which later affects the pricing of equity prices.

From the perspective of cost of equity financing, the working quality of political institution determines the external cost of financing in the form of a financial constraint. The higher the political risks, the higher the perceived risk for equity financing. Boubakri et al. (2014) classifies political institutions as a non-diversifiable risk, which will require a higher risk premium. Countries with strong political institutions are expected to be more transparent and implement more people-friendly policies (Bushman et al., 2004; Coles et al., 1994; Lambert et al., 2007), which in turn reduces the information risks. Lower risk is translated into lower cost of capital. Strong political institutions have better enforcement of the law that reduces corruption, out-of-pocket expenses on monitoring and other costs arising due to asymmetries in information. In short, the presence of a strong political institution corresponds to lower cost of capital.

On the same note, Pastor and Veronesi $(2012,2013)$ developed a theoretical model on how political uncertainty affects asset prices and volatility. Their political signaling theory models how stock prices respond to political news. The original model postulates the idea that market responds to the promises or words of politicians. The political news serves as a signal, which indicates future policies or changes in policies in the near future. A more general study by Bloom et al. (2007) and Bloom (2009) document empirical findings how increases in uncertainty after a major event have adverse effects on investment, output and employment. More specific studies by Gulen and Ion (2016), Baker et al. (2016), Kelly (2016) and Liu (2017) show how policy uncertainty arising from political uncertainty negatively affect corporate investment. The basic argument is political uncertainty increases the higher risk premium leading to stocks become more volatile.

\subsection{Housing in Malaysia}

Political institutions can interfere with the housing policy in several ways. Malaysia is facing an acute mismatch between demand and supply for low and medium cost housing since developer prefer high end housing development which garners higher profits. In 1997, the Ministry of Finance established Syarikat Perumahan Negara (SPNB) to assuage the problem of mismatch and to address the problem of housing amongst the poor. SPNB launced Rumah Mesra Rakyat (RMR - Citizen Friendly Homes) and Rumah Mampu Milik (RMM Affordable Homes) for household with income less than RM2000 per month and took over a number of abandoned housing projects. In 1998 the government introduced Integrated Public Low-Cost Housing Scheme (IPLC) which focuses on building low cost flats to overcome the problem of squatters in Kuala Lumpur and other major cities in Malaysia. Those unqualified for IPLC but still falls under the low-income category could apply for Site and Services Scheme (SSS).

More concerted efforts were undertaken to help bottom 40 per cent (B40) and middle 40 percent (M40) of the population purchased their own home by providing affordable housing schemes and eight (8) housing projects. Table 1 summarizes the list of government intervention projects for housing.

Perumahan Rakyat 1Malaysia (PR1MA - Malaysian Housing Project) was launched in 2012 to develop affordable homes for household with monthly income between RM2,500 - RM7,500. In 2016, 81,352 units of Project Perumahan Rakyat (PPR - Citizen Housing Project) projects have been completed and a total of RM45.482 million housing loans has been given to 1,011 applicants. Despite the intensified government intervention to provide affordable housing for low income earners, the supply of low cost housing is still inadequate and housing prices continue to escalate as construction cost increase. This paper examines the role of 
political institutions and impact of elected government on housing prices in Malaysia.

Table 1. List of Government Housing-related Intervention Projects in Malaysia

\begin{tabular}{lll}
\hline & Name of Scheme & Projects by: \\
\hline 1. & Skim Perumahan Rakyat 1Malaysia (PR1MA) & Federal Government \\
2. & Skim Perumahan Mampu Milik Swasta (MyHome1 \& 2) & Private \\
3. & Perumahan Penjabat Awam 1Malaysia (PPA1M) & Federal Government \\
4. & Program Perumahan Rakyat (PPR) & Federal Government \\
5. & Rumah Mesra Rakyat 1Malaysia (RMR1M) & Federal Government \\
6. & Rumah Selangorku (RS) & State Government \\
7. & Rumah Mampu Milik Wilayah Persekutuan (RUMAWIP) & Federal Territories \\
8. & Rumah Idaman Rakyat (RIR) & Federal Government \\
9. & Bantuan Sewa (Rent Assistance) & Federal Government \\
& Total Recipients (number of households): & \\
& $2012-7,778$ & \\
& $2013-6,628$ & \\
& $2014-6,641$ & \\
& $2015-6,711$ & \\
\hline
\end{tabular}

Source: Ministry of Urban Wellbeing, Housing and Local Government (various years), Department of Urban Wellbeing (2016), Department of National Housing (2017)

\section{Methodology}

This section elaborate on the modelling specification, estimation method and data sources.

\subsection{Model Specification}

Following the basic specification by Post and Berkhout (2014) and Case (2000), the empirical model to be estimated is as follows:

$$
\ln H P_{t}=\alpha_{0}+\beta_{1} \ln Y_{t}+\beta_{2} \ln W_{t}+\beta_{3} \ln E R_{t}+\beta_{5} \ln L R_{t}+\beta_{6} P O L_{t}+\varepsilon_{t}
$$

where $H P$ is the housing price, $Y$ is income, $W$ is the number of workers in the workforce or labour participation rate, $E R$ is the exchange rate which captures the external environment, $L R$ is the average lending rate and $P O L$ captures the political variables.

We examine the impact of political institutions on housing prices in Malaysia. Other potential control variables such as inflation, savings, crisis dummies, pre-and post-crisis dummies, and financial openness were used but later dropped due to their insignificant effect and to ensure parsimony in modelling.

\subsection{Estimation Technique}

Pesaran and Shin (1999) bounds testing procedure within the autoregressive distributed lag (ARDL) framework is used to establish cointegration between housing price and political variables. A six variable cointegration system tests for level relationships between the housing price, five (5) control variables and the political institution variable. Following this procedure, the variables in the cointegration system can either be integrated of order $1, I(1)$ or $0, I(0)$ but the dependent variable, HP must be $I(1)$ (Pesaran et al., 2001). To confirm the level of integration and the absence of structural break, the ADF test and unit root test with a breakpoint based on Perron (1989) is used on all the specified variables. The ARDL approach to cointegration offers several advantages. First, it can be used in an equation with a mixture of $I(0)$ and $I(1)$ level of stationarity as long as the dependent variable is $I(1)$ and bounds test surpasses the upper critical value. Second, ARDL is ideal for this study due to its small sample properties. Johansen and Juselius VECM requires large data points, thus, unsuitable for this study. Third, ARDL captures the data generating process by allowing sufficient number of lags without compromising on the efficiency of the regression. In turn, the selection of appropriate number of lags suppresses endogeneity problem rendering ARDL model almost free from residual correlation. Unlike, FM-OLS or DOL which provides long run estimated coefficients only, ARDL offers short run adjustments via the error correction mechanism through a simple linear transformation without affecting the long run coefficients. However, ARDL technique collapses in if any of the variables are integrated of order 2, I(2). In this study, we perform ADF unit root test to check the order of integration of each variable. Housing price (HP) is $I(1)$ and all other dependent variables are a mixture of $I(0)$ and $I(1)$. The long run relationship is estimated as follows: 


$$
\begin{aligned}
\Delta l n H P_{t}=\alpha_{0}+ & \beta_{1} \sum_{i=1}^{p} \Delta Y_{t-i} \\
& +\beta_{2} \sum_{i=1}^{p} \Delta g d p_{-} g_{t-i}+\beta_{3} \sum_{i=1}^{j=n} \Delta l a b_{-} p a r t_{t-i} \\
& +\beta_{4} \sum_{i=1}^{j=n} \Delta A L R_{t-i}+\beta_{5} \sum_{i=1}^{j=n} \Delta p o l_{t-i}+\varphi_{1} \ln H P_{t-i}+\varphi_{2} \ln g d p_{-} g_{t-i} \\
& +\varphi_{3} \ln l a b_{-} p_{t-i}+\varphi_{4} \ln g A L R_{t-i}+\varphi_{5} \ln p o l_{t-i}+\varepsilon_{t}
\end{aligned}
$$

where $\beta_{0}$ is the the drift term and is $\varepsilon_{t}$ the error term. The dynamics of the short run error correction components are denoted by the terms with summation signs whilst the long run relationship is represented by $\varphi$.

The existence of a long run relationship is examined using joint F-statistics or Wald statistics via null hypothesis of no cointegration such that:

$$
H_{0}=\sigma_{1}=\sigma_{2}=\sigma_{3}=\sigma_{4}=\sigma_{5}=0
$$

and the alternative hypothesis is:

$$
H_{0} \neq \sigma_{1} \neq \sigma_{2} \neq \sigma_{3} \neq \sigma_{4} \neq \sigma_{5} \neq 0
$$

Based on Pesaran et al. (2001), bounds testing determines the existence of long run relationship amongst the variables. If the calculated F-statistics is greater than the upper band critical value, the null hypotheses is rejected implying the presence of cointegration, regardless the variables being stationary at level, $I(0)$ or at first difference, I(1). Alternatively, if the calculated F-statistics is less than the lower bound critical value, the null hypothesis of no long run relationship cannot be rejected. Bounds test will be inconclusive if the calculated F-statistics falls between the lower and upper band of the critical value. The optimal lag length is chosen based on the Akaike Information Criteria (AIC), based on ARDL method which estimates the number of regressions $(p+1)_{k}$, where $p$ is the number of lags and $k$ is the number of variables in the equation. Following the bound tests and optimal lag selection, given the existence of cointegration, the error correction model representation is as follows:

$$
\operatorname{lnH} P_{t}=\alpha_{0}+\beta_{1} \sum_{i=1}^{j=n} \Delta g d p_{-} g_{t-i_{t}}+\sum_{i=1}^{j=n} \Delta l a b_{-} p_{a r t} t_{t-i}+\sum_{i=1}^{j=n} \Delta A L R_{t-i}+\sum_{i=1}^{j=n} \Delta \text { pol }_{t-i}+e c t_{t}+\varepsilon_{t}
$$

where ect is the speed of adjustment towards the long run equilibrium. We perform diagnostic test such as serial correlation, normality, heteroscedasticity and functional form to check the robustness of the estimation. CUSUM and CUSUMSQ test is carried out to examine the overall stability of the model. If statistics are within the critical bound of the $5 \%$ level of significance, we can conclude that the regression is stable since the null hypothesis cannot be rejected.

\subsection{Data Definitions and Sources}

Table 2 summarizes the definition of the variables and their measurements, the sources of the variables and the years available for regression analysis.

Table 2. Data definitions and sources of variables

\begin{tabular}{clcc}
\hline Acronym & \multicolumn{1}{c}{ Definition\& measurement } & Source & Years \\
\hline hpi_g & Growth of housing price & NAPIC, BNM & $1988-2015$ \\
gdp_g & Growth of gdp (year-on-year) & Department of & $1988-2015$ \\
ave_lend_rate & Average lending rate & Statistics & $1988-2015$ \\
labour_part & Labour participation & BNM & $1988-2015$ \\
reer & Real effective exchange rte & WDI & $1988-2015$ \\
elec & Year of election & IFS, IMF & $1988-2015$ \\
b_elec & Year before election & Database of & $1988-2015$ \\
p_elec & Year after election & Political & $1988-2015$ \\
\hline
\end{tabular}




\begin{tabular}{|c|c|c|c|}
\hline tensys & Tenure of the ruling government & World Bank (DPI) & $1988-2015$ \\
\hline checks_lax & Countries where legislatures are not competitively elected & DPI & $1988-2015$ \\
\hline polariz & $\begin{array}{l}\text { Maximum polarization between executive party and principle } \\
\text { parties of legislature }\end{array}$ & DPI & $1988-2015$ \\
\hline finittrm & Finite term in office & DPI & \\
\hline execme & chief executive is independent & DPI & \\
\hline allhouse & party of the executive have absolute majority in the house & DPI & $1988-2015$ \\
\hline herftot & Herfindahl Index (Total) & DPI & $1988-2015$ \\
\hline govfrac & $\begin{array}{l}\text { probability that two deputies picked at random from amongst } \\
\text { government parties }\end{array}$ & DPI & $1988-2015$ \\
\hline partyage & average age of the parties & DPI & $1988-2015$ \\
\hline ef & Total score for economic freedom & Fraser Institute & $1988-2000$ \\
\hline ef1 & Property rights & Fraser Institute & $2000-2015$ \\
\hline ef2 & Government spending freedom & Fraser Institute & $2000-2015$ \\
\hline ef3 & Business freedom & Fraser Institute & $2000-2015$ \\
\hline ef4 & Labour freedom & Fraser Institute & $2000-2015$ \\
\hline ef5 & Monetary freedom & Fraser Institute & $2000-2015$ \\
\hline ef6 & Trade freedom & Fraser Institute & $2000-2015$ \\
\hline ef7 & Investment freedom & Fraser Institute & $2000-2015$ \\
\hline ef8 & Financial freedom & Fraser Institute & $2000-2015$ \\
\hline cor & Control of corruption & Worldwide & $2000-2012$ \\
\hline g_eff & Government effectiveness & Governance Index, & $2000-2012$ \\
\hline p_stab & Political stability/ bsence of violence /terrorism & World Bank (WGI) & $2000-2012$ \\
\hline reg & Regulatory quality & WGI & $2000-2012$ \\
\hline rol & Rule of law & WGI & $2000-2012$ \\
\hline va & Voice \& accountability & WGI & $2000-2012$ \\
\hline
\end{tabular}

\section{Results and Discussions}

Table 3 shows the impact of election outcomes on housing prices. Pre-election and election dummies are both positive and significant rendering the positive expectations during pre-electing and election years which positively impacted housing prices. In line with the business political model, the post-election impact is negative as the elected government continue with their economic agenda such as curbing speculation in housing prices. The imposition of higher real property gain tax (RPGT) for example was imposed on buyers who dispose their property in less than 5 years. In the case of Malaysia, the legislatures are not independent and are not competitively elected (checks_lax); and has been under parliamentary democracy for the past 50 years (tensys) and have impacted housing price in a positive manner.

Table 3. Short and Long Run Impact of Elections Outcomes on Housing Price

\begin{tabular}{lllllll}
\hline & \multicolumn{5}{c}{ Long run Coefficients } \\
\cline { 2 - 7 } & pre election & elec & post_elec & tensys & checks_lax & polariz \\
\hline gdp_g & -0.2789 & -01783 & -0.4388 & $0.3063^{* *}$ & $0.3297^{* *}$ & 0.3048 \\
& $(0.2523)$ & $(0.2049$ & $(0.2543)$ & $(0.1228)$ & $(0.1158)$ & $(0.5126)$ \\
reer & $0.4740^{* * *}$ & $0.4466^{* * *}$ & $0.4878^{* * *}$ & $0.2053^{*}$ & $0.2575^{* *}$ & -0.7187 \\
& $(0.0669)$ & $(0.0535)$ & $(0.0623)$ & $(0.4568)$ & $(0.1055)$ & $(1.4445)$ \\
labour_participation & $1.2404^{* * *}$ & $1.2111^{* * *}$ & $1.2208^{* * *}$ & $1.1084^{* *}$ & $0.7264^{* *}$ & -4.0071 \\
& $(0.2249)$ & $(0.2118)$ & $(0.2276)$ & $(0.4586)$ & $(0.2484)$ & $(7.0846)$ \\
a_lending_rate & $-1.6125^{* * *}$ & $-1.5322^{* * *}$ & $-1.6001^{* * *}$ & $-1.1193^{* *}$ & $-1.2128^{* *}$ & -0.6541 \\
& $(0.2257)$ & $(0.1898)$ & $(0.2058)$ & $(0.4229)$ & $(0.4283)$ & $(1.8552)$ \\
constant & $-110.115^{* * *}$ & $-106.3067 * * *$ & $-107.3558^{* * *}$ & $-96.8782^{* *}$ & $-67.1709 * * *$ & 346.1378 \\
& $(15.1959)$ & $(13.6949)$ & $(14.6603)$ & $(31.6969)$ & $(18.8243)$ & $(596.9647)$ \\
pol_variable & $4.8220^{* *}$ & $3.4686^{* * *}$ & $-3.9693^{*}$ & $0.3689^{* *}$ & $0.2748^{* *}$ & -5.2695 \\
& $(2.0793)$ & $(1.1231)$ & $(2.0895)$ & $(0.1572)$ & $(0.1465)$ & $(7.7412)$ \\
\hline
\end{tabular}




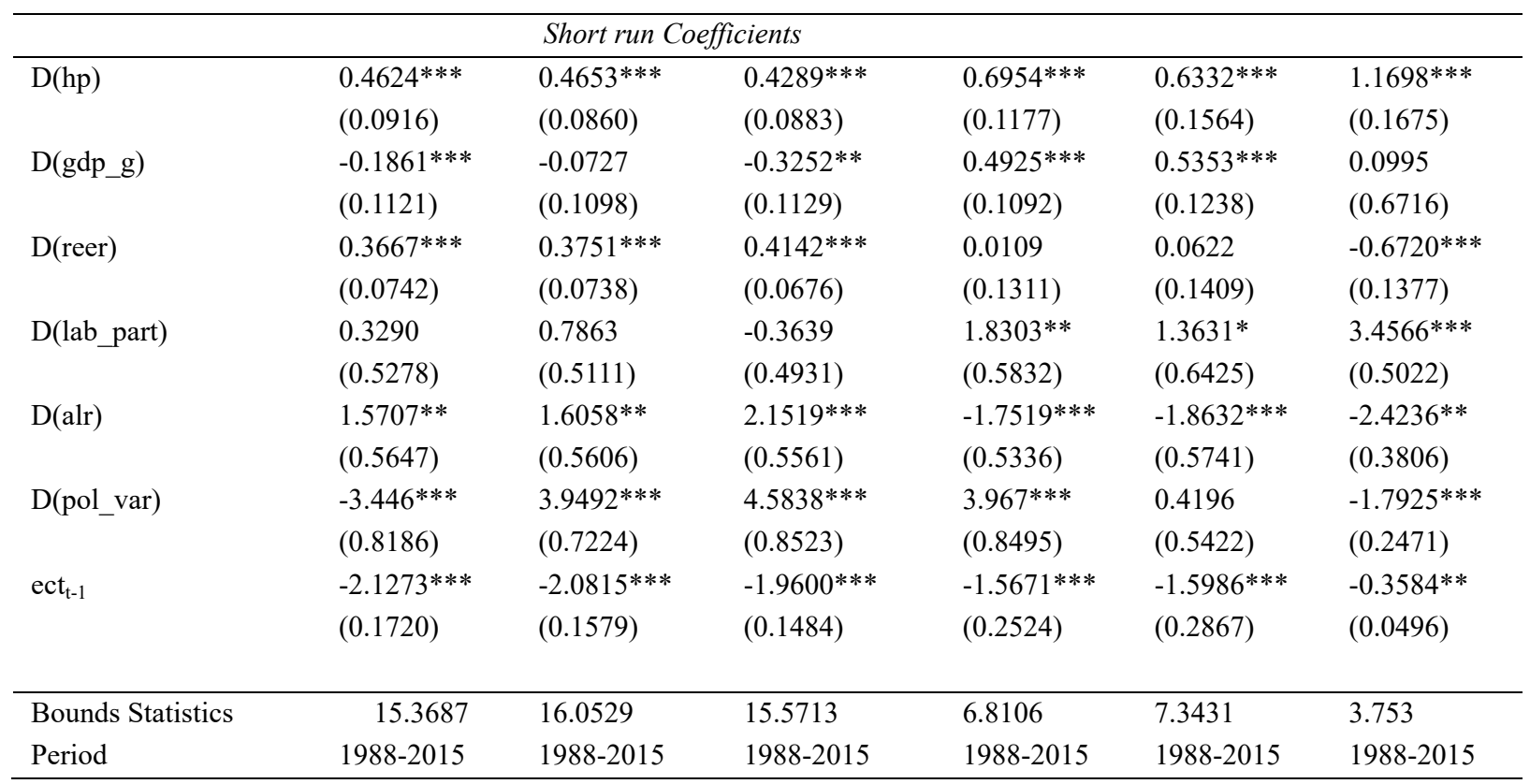

Notes: 5\% upper bound stats (restricted intersect and no trend) $=3.34$ (Pesaran et al., 2001). checks_lax shows countries where legislatures are not competitively elected; tensys - tenure of the ruling government; pre_elec-pre-election years; elec - election year; post_elec - post election years; polariz - maximum polarization between executive party and principle parties of legislature $* * *, * *$ and $*$ denote $1 \%, 5 \%$ and $10 \%$ significant level.

Table 3. continue

\begin{tabular}{|c|c|c|c|c|c|c|c|}
\hline \multicolumn{8}{|c|}{ Long run Coefficients } \\
\hline & finittrm & execme & allhouse & herftot & govfrac & partyage & herfgov \\
\hline \multirow[t]{2}{*}{ gdp_g } & $0.3571 * * *$ & $0.3063 * *$ & $0.3063 * *$ & 1.2885 & 1.1719 & -4.4173 & -3.8414 \\
\hline & $(0.0889)$ & $(0.1228)$ & $(0.1228)$ & $(0.3654)$ & $(0.3127)$ & $(8.6664)$ & $(9.1885)$ \\
\hline \multirow[t]{2}{*}{ reer } & $0.2727 * *$ & $0.2053^{*}$ & $0.2053^{*}$ & -0.0149 & 0.0309 & 0.9494 & 0.2587 \\
\hline & $(0.1021)$ & $(0.1103)$ & $(0.1103)$ & $(0.1161)$ & $(0.0930)$ & $(1.4326)$ & $(0.7054)$ \\
\hline \multirow[t]{2}{*}{ lab_part } & $0.6341 * *$ & $1.1084 * *$ & $1.1084 * *$ & -0.8822 & -0.6158 & 2.1173 & -0.2594 \\
\hline & $(0.2737)$ & $(0.4686)$ & $(0.4586)$ & $(0.5882)$ & $(0.3954)$ & $(2.3901)$ & $(2.0743)$ \\
\hline \multirow[t]{2}{*}{ alr } & $-1.0894 * * *$ & $-1.1193 * *$ & $-1.1193 * *$ & -2.3405 & -2.3847 & -5.1758 & -5.1156 \\
\hline & $(0.2549)$ & $(0.4229)$ & $(0.4229)$ & $(0.3073)$ & $(0.2779)$ & $(5.8843)$ & $(6.7421)$ \\
\hline \multirow[t]{2}{*}{ constant } & $-56.7858 * *$ & $-95.4027 * *$ & $-90.2386^{* *}$ & 78.4187 & 37.1477 & -208.9152 & 21.5547 \\
\hline & $(23.2932)$ & $(31.4621)$ & $(30.7277)$ & $(47.4248)$ & $(29.7411)$ & $(274.647)$ & $(164.8001)$ \\
\hline \multirow[t]{2}{*}{ pol_var } & $-0.1676^{* * *}$ & $0.3689 * *$ & $0.3689 * *$ & -2.6344 & $29.1137 * * *$ & 51.4248 & 0.9429 \\
\hline & $(0.0473)$ & $(0.1572)$ & $(0.1572)$ & $(6.8937)$ & $(6.1615)$ & $(90.8669)$ & $(2.2669)$ \\
\hline \multicolumn{8}{|c|}{ Short run Coefficients } \\
\hline \multirow[t]{2}{*}{$\mathrm{D}(\mathrm{hp})$} & $0.6983 * * *$ & $0.5437 * *$ & $0.5439 * * *$ & $0.6589^{* * *}$ & $0.6493 * * *$ & $0.6587 * * *$ & $0.6619 * * *$ \\
\hline & $(0.1193)$ & $(0.1817)$ & $(0.1818)$ & $(0.1416)$ & $(.01316)$ & $(0.1145)$ & $(0.1294)$ \\
\hline \multirow[t]{2}{*}{$\mathrm{D}\left(\mathrm{gdp} \_\mathrm{g}\right)$} & $0.5577 * * *$ & $0.4925 * * *$ & 0.4925 & $1.1599 * * *$ & $1.1289 * * *$ & $-0.6603 * * *$ & $-0.5512 * * *$ \\
\hline & $(0.09)$ & $(0.1092)$ & $(0.1092) * * *$ & $(0.1424)$ & $(0.1458)$ & $(0.1420)$ & $(0.0827)$ \\
\hline \multirow[t]{2}{*}{$\mathrm{D}$ (reer) } & -0.1937 & 0.0109 & 0.0109 & $-0.6129 * * *$ & $-0.5508 * * *$ & $0.2681^{*}$ & $0.3044 * * *$ \\
\hline & $(0.1067)$ & $(0.1312)$ & $(0.1310)$ & $(0.1045)$ & $(0.1037)$ & $(0.1265)$ & $(0.0866)$ \\
\hline \multirow[t]{2}{*}{$\mathrm{D}($ lab_part $)$} & $2.5177 * * *$ & $1.8303^{* *}$ & $1.8303^{* *}$ & $2.2342 * * *$ & $1.9388 * * *$ & $0.9905^{* *}$ & $0.9145^{* *}$ \\
\hline & $(0.4541)$ & $(0.5832)$ & $(0.5832)$ & $(0.3459)$ & $(0.3622)$ & $(0.6224)$ & $(0.3832)$ \\
\hline \multirow[t]{2}{*}{$\mathrm{D}($ alr $)$} & $-1.903 * * *$ & $-1.7519 * * *$ & $-1.7519 * *$ & $-4.1699 * * *$ & $-4.0348 * * *$ & $-1.1496 * *$ & -1.3959 \\
\hline & $(0.3814)$ & $(0.5336)$ & $(0.5336)$ & $(0.3836)$ & $(0.3949)$ & $(0.5055)$ & $(0.3172) * * *$ \\
\hline \multirow[t]{2}{*}{ D(pol_var) } & $-0.1676^{* * *}$ & $3.967^{* * *}$ & $3.967 * * *$ & $27.0745^{* * *}$ & $-24.658 * * *$ & $17.6944 * * *$ & $0.6594 * * *$ \\
\hline & $(0.0473)$ & $(0.8495)$ & $(0.8495)$ & $(4.6395)$ & $(5.0533)$ & $(5.8910)$ & $(0.0971)$ \\
\hline
\end{tabular}




\begin{tabular}{llllllll}
\hline ect $\mathrm{t}_{-1}$ & $-1.5141^{* * *}$ & $-1.5671^{* * *}$ & $-1.5671^{* * *}$ & $-1.5120 * * *$ & $-1.6018 * * *$ & $-0.2761 * * *$ & $-0.2480^{* * *}$ \\
& $(0.1855)$ & $(0.2524)$ & $(0.2524)$ & $(0.1548)$ & $(0.1704)$ & $(0.0457)$ & $(0.2726)$ \\
\hline $\begin{array}{l}\text { Bounds } \\
\text { Statistics }\end{array}$ & 6.2412 & 6.1656 & 6.8106 & 6.1834 & 3.7641 & 7.8035 & 8.3616 \\
Period & $1988-2015$ & $1988-2015$ & $1988-2015$ & $1988-2015$ & $1997-2015$ & $1988-2015$ & $1988-2015$ \\
\hline
\end{tabular}

Notes: $5 \%$ upper bound stats (restricted intersect and no trend) $=3.34$. finittrm - finite term in office; execme - chief executive is independent; allhouse - party of the executive have absolute majority in the house; herftot - Herfindahl Index (Total); govfrac- probability that two deputies picked at random from amongst government parties; partyage - average age of the parties. ***, ** and * denote $1 \%, 5 \%$ and $10 \%$ significant level.

Results suggest a negative relationship between constitutional limits on the number of years in the office the executive (finittrm) can serve prior to new elections both in the short and long run. The absence of an explicitly written limit on the number of years of service an elected member of parliament or state exco may impede increase in housing prices. Higher independence of the chief executive (prime minister, in the case of Malaysia) is positively related to housing prices. With the ruling government holding majority of the parliamentary seats, laws and rules can be easily passed, therefore, has a positive impact on housing prices. The Herfindahl Index (herftot) is positive in the short run but insignificant in the long run suggesting the impact of the number of seats by government or opposition in short term in nature. Results are support by positive and significant Herfindahl Index for government (hertgov) in the short run but insignificant in the long run. Govfrac shows the probabilities of two deputies are elected from the ruling government parties being positively correlated with housing price due to its predictability. Similarly, the average age of the party (partyage) has significant positive impact on housing prices only in the long run.

Table 4 illustrates the short and long run impact of governance on housing prices. Voice and accountability (va) measures 'the extent to which country's citizen are able to participate in selecting their government, as well as freedom of expression, freedom of association and free media" (Kaufman et al., 2005), significantly impacted housing price both in the short and long term. The rule of law (rol) measures the extent of citizens having confidence and abide the rules of the society, enforcement of police and courts, and that good enforcement of the rule and laws reduces the likelihood of crime and violence. Rule of law captures enforceable contracts which can promote and protect business and commercial activities, rules and laws being transparent and enforceable, protection of individual property rights and access to justice. In this study, rule of law has a positive impact on housing prices in the long run. Such circumstances would improve livelihood and promote the development of new housing projects to cater for other needs such as leisure, more space for play, community hall, community center, sports center and others. These results infer the importance of good governance in promoting the growth and development of housing in Malaysia. These findings are in line with Bushman et al. (2004), Coles et al. (1994) and Lambert et al. (2007).

Table 4. Short and Long Run Impact of Governance on Housing Price

\begin{tabular}{llllll}
\hline \multicolumn{5}{c}{ Long run Coefficients } \\
\cline { 2 - 6 } & 1 (gov_eff) & 2 (p_stab) & $3(\mathrm{reg})$ & 4 (rol) & $5(\mathrm{va})$ \\
\hline gdp_g & -1.6961 & -0.8330 & -2.1908 & $0.2647^{*}$ & $0.4076^{* *}$ \\
reer & $(1.6738)$ & $(1.5647)$ & $(3.0778)$ & $(0.14)$ & $(0.1228)$ \\
& 0.9948 & 0.9453 & 0.5609 & $0.6163^{* * *}$ & $0.1649^{*}$ \\
labour_participation & $(0.5526)$ & $(0.7307)$ & $(0.5028)$ & $(0.1521)$ & $(0.106)$ \\
& $3.0911^{* *}$ & 0.5055 & -0.1541 & 0.6392 & -0.554 \\
a_lending_rate & $(1.370)$ & $(0.7613)$ & $(1.7592)$ & $(0.4585)$ & $(0.5116)$ \\
& -0.049 & $-3.205 * *$ & -3.5884 & $-2.5788^{* * *}$ & $-2.0422^{* * *}$ \\
constant & $(1.2134)$ & $(1.4761)$ & $(2.0937)$ & $(0.3633)$ & $(0.2138)$ \\
& $-322.7929^{* *}$ & -98.4558 & -16.218 & $-76.5531^{* * *}$ & 39.4698 \\
pol_variable & $(163.50)$ & $(68.1642)$ & $(95.3453)$ & $(19.4347)$ & $(38.8974)$ \\
& 38.6717 & -2.0872 & 17.7654 & $19.0507^{* *}$ & $12.7956^{* *}$ \\
\hline & $(24.7472)$ & $(2.5012)$ & $(24.8170)$ & $(6.5518)$ & $(4.1165)$ \\
\hline D(hp) & & Short run Coefficients & & $0.6268^{* * *}$ \\
D(gdp_g) & & $-0.2528^{* *}$ & $-0.6499 * * *$ & $0.3094^{* * *}$ & 0 \\
\hline
\end{tabular}




\begin{tabular}{llllll}
\hline & $(0.1004)$ & $(0.0954)$ & $(0.1286)$ & $(0.0800)$ & $(0.0952)$ \\
D(reer) & $0.5860 * * *$ & 0.1025 & 0.2045 & -0.0149 & $-0.5181^{* * *}$ \\
& $(0.1247)$ & $(0.1384)$ & $(0.1171)$ & $(0.1064)$ & $(0.1278)$ \\
D(labour_participation) & $1.8770^{* * *}$ & 0.2142 & 0.0071 & 0.6392 & $2.5805^{* * *}$ \\
& $(0.47)$ & $(0.5954)$ & $(0.6393)$ & $(0.4585)$ & $(0.4513)$ \\
D(a_lending_rate) & -0.2481 & $-1.8388^{* *}$ & -0.7529 & $-2.5789 * * *$ & $-1.9607 * * *$ \\
& $(0.47)$ & $(0.4494)$ & $(0.4989)$ & $(0.3633)$ & $(0.3813)$ \\
D(pol_variable) & 4.0815 & 11.6600 & -5.6820 & -0.9862 & $19.5250^{* * *}$ \\
& $(3.0730)$ & $(13.2698)$ & $(4.0381)$ & $(4.3820)$ & $(3.7835)$ \\
ect & $-0.6163 * * *$ & $-0.6252 * * *$ & $-0.5145 * * *$ & $-1.1832 * * *$ & $-1.564 * * *$ \\
& $(0.0762)$ & $(0.0893)$ & $(0.07)$ & $(0.1321)$ & $(0.1863)$ \\
\hline Bounds Statistics & 8.1684 & 6.7277 & 7.1937 & 5.1155 & 2.8955 \\
Period & $1996-2015$ & $1996-2015$ & $1996-2015$ & $1996-2015$ & $1996-2015$ \\
\hline
\end{tabular}

Notes: $5 \%$ upper bound stats (restricted intersect and no trend) $=3.34$. government effectiveness (gov_eff), political stability $\left(p \_s t a b\right)$, regulation $(\mathrm{reg})$, rule of law $(\mathrm{rol})$, voice and accountability $(\mathrm{va}) . * *, * *$ and $*$ denote $1 \%, 5 \%$ and $10 \%$ significant level.

Critics of the World Governance Index (WGI) argue that voice and accountability ( $v a$ ) do not necessarily measure accountability or any other political freedom, hence, rendering the conclusions made using the data pre-mature (Thomas, 2010). In general, WGI data is based on perceptions and not the actual occurrence or events of what it intends to measure, rendering an incorrect reliance on the data to measure overall governance across countries over time. Nevertheless, despite these criticisms, we argue that this provides an indication of the effect of governance in a country and currently, only WGI provides data to enable empirical analysis. Further development and improvement in WGI would mitigate the 'construct validity' issues in the future.

Table 5. Short and Long Run Impact of Economic Freedom on Housing Price

\begin{tabular}{|c|c|c|c|c|c|c|c|c|c|}
\hline \multicolumn{10}{|c|}{ Long run Coefficients } \\
\hline & ef & ef1 & ef 2 & ef3 & ef4 & ef5 & ef6 & ef7 & ef8 \\
\hline \multirow[t]{2}{*}{ gdp_g } & $0.3735^{* * *}$ & -0.2532 & 0.1336 & $-0.8763 * * *$ & $0.3426^{* *}$ & -1.1714 & $0.2889^{* *}$ & $0.3813^{* * *}$ & $0.3722 * * *$ \\
\hline & $(0.1115)$ & $(0.6581)$ & $(0.2332)$ & $(0.8140)$ & $(0.1081)$ & $(1.8722)$ & $(0.1035)$ & $(0.118)$ & $(0.0952)$ \\
\hline \multirow[t]{2}{*}{ reer } & $0.3447 * *$ & $0.4014 * *$ & $0.4158^{*}$ & $0.2616^{*}$ & $0.3213^{* *}$ & 0.2633 & $0.3976^{* * *}$ & $0.3036^{* *}$ & $0.3625^{* * *}$ \\
\hline & $(0.1458)$ & $(0.1597)$ & $(0.2095)$ & $(0.1303)$ & $(0.1018)$ & $(0.2615)$ & $(0.1042)$ & $(0.1106)$ & $(0.0942)$ \\
\hline \multirow[t]{2}{*}{ lab_part } & 0.5155 & $0.8508^{* *}$ & -0.2344 & 0.0990 & $0.8434 * * *$ & 0.6568 & $0.9891 * * *$ & 0.0320 & $0.6298 * *$ \\
\hline & $(0.342)$ & $(0.3653)$ & $(0.9031)$ & $(0.6303)$ & $(0.2294)$ & $(0.7585)$ & $(0.2509)$ & $(0.394)$ & $(0.2137)$ \\
\hline \multirow[t]{2}{*}{ alr } & $-1.6487 * * *$ & $-1.3494 * *$ & $-4.9333^{*}$ & $-2.2834 * * *$ & $-1.3260 * * *$ & $-2.4507 * *$ & $-1.0539 * *$ & $-2.3266^{* * *}$ & $-1.5826 * * *$ \\
\hline & $(0.23)$ & $(0.5331)$ & $(2.27)$ & $(0.3884)$ & $(0.3066)$ & (1.0916) & $(0.3757)$ & $(0.2855)$ & $(0.1935)$ \\
\hline \multirow[t]{2}{*}{ constant } & $-71.7621 * *$ & $-97.3368^{* *}$ & -52.8051 & $-93.5211 * * *$ & -93.3021 & -46.2752 & $-107.2767 * * *$ & $-46.3231 *$ & $-107.2699 * * *$ \\
\hline & (30.4209) & (34.2449) & $(32.7342)$ & $(28.0736)$ & $(21.3143)$ & $(65.1676)$ & $(25.2202)$ & (20.8509) & $(20.4957)$ \\
\hline \multirow[t]{2}{*}{ econ_free } & $2.9985^{*}$ & 2.658 & 9.1350 & $12.3776^{* *}$ & $2.3572 * *$ & 0.4307 & $1.7619^{* *}$ & $4.8861 * *$ & $9.0391 * * *$ \\
\hline & $(1.4923)$ & $(1.7448)$ & $(6.6526)$ & $(7.0811)$ & $(0.9810)$ & $(1.5656)$ & $(0.7215)$ & $(1.8622)$ & $(2.5403)$ \\
\hline \multicolumn{10}{|c|}{ Short run Coefficients } \\
\hline \multirow[t]{2}{*}{ D(gdp_g) } & $0.5046 * * *$ & 0.0235 & 0.1034 & $-0.4451 * * *$ & $0.5525 * * *$ & $-0.3207 * *$ & $0.4943 * * *$ & $0.4946 * * *$ & $0.5407 * * *$ \\
\hline & $(0.0876)$ & $(0.074)$ & $(0.0819)$ & $(0.1047)$ & $(0.1158)$ & $(0.1156)$ & $(0.1002)$ & $(0.0917)$ & $(0.0946)$ \\
\hline \multirow[t]{2}{*}{$\mathrm{D}($ reer $)$} & -0.1935 & 0.1592 & -0.0689 & $0.2276^{*}$ & 0.0795 & 0.1032 & 0.1537 & -0.0332 & -0.0372 \\
\hline & $(0.1089)$ & $(0.1137)$ & $(0.1206)$ & $(0.1053)$ & $(0.1312)$ & $(0.1472)$ & $(0.1287)$ & $(0.113)$ & $(0.1108)$ \\
\hline \multirow[t]{2}{*}{$\mathrm{D}$ (lab_part) } & $1.7773 * * *$ & 0.8709 & -0.1866 & -0.0388 & $1.3862^{* *}$ & $0.5335^{* *}$ & $1.4504 * *$ & 0.1255 & $1.1113^{*}$ \\
\hline & $(0.4637)$ & $(0.5335)$ & $(0.6347)$ & $(0.5071)$ & $(0.5952)$ & $(0.6988)$ & $(0.5458)$ & $(0.5632)$ & $(0.5106)$ \\
\hline \multirow[t]{2}{*}{$\mathrm{D}$ (alr) } & $-2.2430 * * *$ & $-1.5305^{* * *}$ & $-2.9751 * * *$ & -0.6348 & $-2.1922 * * *$ & -1.2931 & $-1.8223 * * *$ & $-2.6827 * * *$ & $-2.4993 * * *$ \\
\hline & $(0.3912)$ & $(0.4441)$ & $(0.4685)$ & $(0.4672)$ & $(0.4882)$ & $(0.5579)$ & $(0.4558)$ & $(0.4217)$ & $(0.4160)$ \\
\hline
\end{tabular}




\begin{tabular}{|c|c|c|c|c|c|c|c|c|c|}
\hline $\mathrm{D}$ (econ_free) & $6.1722^{* * *}$ & -0.7382 & $7.9848^{* * *}$ & -3.1085 & 3.0008 & -0.0526 & 0.3018 & $5.3757^{* * *}$ & $9.0391 * * *$ \\
\hline & $(1.2778)$ & (1.3524) & (1.3674) & (3.5569) & (1.8442) & (1.1403) & (1.0706) & $(1.3402)$ & $(2.5403)$ \\
\hline \multirow[t]{2}{*}{$e c t_{t-1}$} & $-1.3406^{* * *}$ & $-1.0708^{* * *}$ & $-0.8603 * * *$ & $-0.99787 * * *$ & $-1.5610 * * *$ & $-0.6509 * * *$ & $-1.6264 * * *$ & $-1.4722 * * *$ & $-1.4103^{* * *}$ \\
\hline & $(0.1796)$ & $(0.1439)$ & $(0.1403)$ & $(0.1218)$ & $(0.2589)$ & $(0.1165)$ & $(0.2381)$ & $(0.2261)$ & $(0.2085)$ \\
\hline Bounds Stats & 3.9705 & 8.41 & 5.3121 & 6.5691 & 6.4442 & 7.7844 & 7.9562 & 6.2681 & 5.8422 \\
\hline Period & $1988-2015$ & $2000-2015$ & $2000-2015$ & $2000-2015$ & $2000-2015$ & $2000-2015$ & $2000-2015$ & $2000-2015$ & $2000-2015$ \\
\hline
\end{tabular}

Notes: $5 \%$ upper bound stats (restricted intersect and no trend) $=3.34$. ef-overall score for economic freedom; ef1 - property rights; ef $2-$ government spending freedom; ef 3 - business freedom; ef4 - labour freedom; ef5 - monetary freedom; ef6 - trade freedom; ef 7 - investment freedom; ef8 - financial freedom

Table 5 illustrates how the choice of political regime has impacted the degree of economic freedom which is later translated into housing development and prices. In the long run, the greater overall economic freedom is positively correlated with housing prices which depicts the affordability to buy houses as the economy prosper. Long run results suggest labour, trade, investment and financial freedom are positively associated with long term house price. Labour and investment in the long is vital to ensure continued development capacity or supply side of housing whilst financial freedom guarantees the demand side of housing development. In the short run, only government spending, investment and financial freedom have positive affect on house prices. These results may suggest justification for government intervention in housing prices in Malaysia. Financial freedom may also serve as an indicator for financial inclusion suggesting availability of affordable loan to purchase houses. Similarly, investment freedom relates to the rise in housing development in Malaysia, from the perspective of government related agencies such as PR1MA, private Malaysian developer and foreign developers.

\section{Conclusion}

In this paper, we attempt to establish the impact of election, election outcomes and economic governance on housing prices in Malaysia. Results suggest election outcomes in the form of more democracy, transparency and freedom to choose generally impact housing prices in a positive manner. These outcome is suggestive that democracy begets stability which provides a thriving economic environment, in this case, the development of housing in Malaysia. An important policy implication is that the government must ensure institutional stability as is provides the basis for future development. Strong political will is necessary to curb speculation in housing prices.

\section{References}

Adams, Z. \& Fuss, R. (2010). Macroeconomic determinants of international housing markets. Journal of Housing Economics, 19, 38-50. https://doi.org/10.1016/j.jhe.2009.10.005

Agnello, L., \& Schuknecht, L. (2011). Booms and busts in housing markets: Determinants and implications. Journal of Housing Economics, 20, 171-190. https://doi.org/10.1016/j.jhe.2011.04.001

Ahuja, A., Cheung, L., Han, G. Nathan, Porter, \& Zhang, W. (2010). Are house price rising too fast in China. IMF Working Paper WP/10/274.

Baker, S. R., Bloom, N., \& Davis, S. J. (2016). Measuring economic policy uncertainty. Quarterly Journal of Economics, 131, 1593-1636. https://doi.org/10.1093/qje/qjw024

Bank Negara Malaysia. (2016). Responsible lending guidelines ensures borrowers' affordability. Press Release, Ref. No.: 09/16/04, 20 September.

Bhattacharya, U., \& Daouk, H. (2002). The World Price of Insider Trading. Journal of Finance, 57(1), 75-108. https://doi.org/10.1111/1540-6261.00416

Bloom, N. (2009). The impact of uncertainty shocks. Econometrica, 77, 623-685. https://doi.org/10.3982/ECTA6248

Bloom, N., Bond, S., \& van Reenen, J. (2007). Uncertainty and investment dynamics. Review of Economic Studies, 74, 391-415. https://doi.org/10.1111/j.1467-937X.2007.00426.x

Boubakri, N., El-Ghoul, S., \& Saffar, W. (2014). Political rights and equity pricing. Journal of Corporate Finance, 27, 326-344. https://doi.org/10.1016/j.jcorpfin.2014.05.009

Bushman, R. M., Piotroski, J. D., \& Smith, A. J. (2004). What determines corporate transparency? Journal of Accounting Research, 42(2), 207-252. https://doi.org/10.1111/j.1475-679X.2004.00136.x 
Case, K. E. (2000). Real estate and the macroeconomy. Brooking Papers on Economic Activity, 20(2), 119-162. https://doi.org/10.1353/eca.2000.0011

Catte, P., Girouard, N., Price, R., \& Andre, C. (2004). Housing markets, wealth and the business cycle. OECD Working Paper No. 394. https://doi.org/10.1108/SEF-11-2013-0170

Ciarlone, A. (2015). House price cycles in emerging economies. Studies in Economics and Finance, 32(1), $17-52$.

CIDB Malaysia. (2012, 2016). Labour Wage Rates (General Construction Worker - Building Helper). http://myn3c.cidb.gov.my/cidb_n3c/output/a_web_lwr_details.php?4\#

Coles, J., Loewenstein, U., \& Suay, J. (1995). On Equilibrium Pricing Under Parameter Uncertainty. The Journal of Financial and Quantitative Analysis, 30, 347-374. https://doi.org/10.2307/2331345

Department of Statistics. (2014). Report on Survey of Construction Industries 2014. Kuala Lumpur. Malaysia.

DiPasquale, D., \& Wheaton, W. C. (1996). Urban Economics and Real Estate Markets. Prentice-Hall, Englewood Cliff, New Jersey.

Gaspareniene, L., Remeikiene, R., \& Skuka, A. (2016). Assessment of the impact of macroeconomic factors on housing price level: Lithuanian case. Intellectual Economics, 10, 122-127. https://doi.org/10.1016/j.intele.2017.03.005

Goddard, G. J., \& Marcum, B. (2012). Real estate investment: A value based approach. Berlin: Springer-Verlag. https://doi.org/10.1007/978-3-642-23527-6

Gulen, H., \& Ion, M. (2016). Policy uncertainty and corporate investment. Review of Financial Studies, 29, 523-564.

Hail, L., \& Luez, C. (2006). International Differences in the Cost of Equity of Capital: Do Legal Institutions and Securities Regulation Matter? Journal of Accounting Research, 44(3), 485-531. https://doi.org/10.1111/j.1475-679X.2006.00209.x

Hort, K. (1998). The determinants of urban house price fluctuations in Sweden 1968-1994. Journal of Housing Economics, 7(2), 93-120. https://doi.org/10.1006/jhec.1998.0225

Hott, C., \& Monnin, P. (2008). Fundamental real estate prices: An empirical estimation with international data. The Journal of Real Estate Finance and Economics, 36(4), 427-450. https://doi.org/10.1007/s11146-007-9097-8

Hua, X., Sun, L., \& Borgia, D. (2012). The influence of fundamental factors on Chinese residential real estate prices: a unique data panel study. Nottingham University Business School. Working Paper. https://doi.org/10.2139/ssrn.2022682

Kelly, B., Pastor, L., \& Veronesi, P. (2016). The price of political uncertainty theory: theory and evidence from the option market. Journal of Finance, 71, 2417-2480. https://doi.org/10.1111/jofi.12406

Lambert, R., Luez, C., \& Verrecchia, R. E. (2007). Accounting information, disclosure and the cost of capital. Journal of Accounting Research, 45(2), 385-420. https://doi.org/10.1111/j.1475-679X.2007.00238.x

LaPorta, R., Lopez-de-Silanes, F., Shleifer, F., \& Vishny, R. (1997). Legal determinants of external finance. Journal of Finance, 52(3), 1131-1150. https://doi.org/10.1111/j.1540-6261.1997.tb02727.x

Lin, W. S.. Tou, J. C., Lim, S. Y., \& Yeh, M. Y. (2014). Effects of socio economic factors on regional housing prices in USA. International Journal of Housing Markets and Analysis, 7(1), 30-41. https://doi.org/10.1108/IJHMA-11-2012-0056

Liu, L. X., Shu, H., \& Wei, K. C. J. (2017). The impact of political uncertainty on asset prices: Evidences from the Bo scandal in China. Journal of Financial Economics, 125, 286-310. https://doi.org/10.1016/j.jfineco.2017.05.011

Manganelli, B. (2014). Real estate investing: Market analysis, valuation techniques, and risk management. Cham: Springer International Publishing.

Mankiw, G. N., \& Weil, D. N. (1989).The baby boom, the baby bust, and the housing market. Regional Science and Urban Economics, 19(2), 235-258. https://doi.org/10.1016/0166-0462(89)90005-7

McCord, M., McGreal, S., Berry, J., Haran, M., \& Davis, P. (2011). The implications of mortgage finance on housing market affordability. International Journal of Housing Markets and Analysis, 4(4), 394-417. 
https://doi.org/10.1108/17538271111172175

Ministry of International Trade and Industries (MITI). (2017). Final Determination of Safeguard Investigations with Regard to the Imports of Steel Concrete Reinforcing Bar (REBAR) and Steel Wire Rods \& Deformed Bar in Coil (SWR \& DBIC) Into Malaysia Under the Safeguard Act 2006. Media Release. 13 April 2017.

Oktay, E., Karaaslan, A., Alkan, O., \& Celik, A. K. (2014). Determinants of housing demand in the Erzurum province, Turkey. International Journal of Housing Markets and Analysis, 7(4), 586-602. https://doi.org/10.1108/IJHMA-11-2013-0056

Pagano, M., \& Volpin, P. (2001). The Political Economy of Finance. Oxford Review of Economic Policy, 17(4), 502-519. https://doi.org/10.1093/oxrep/17.4.502

Pastor, L., \& Veronesi, P. (2012). Uncertainty about government policy and stock prices. Journal of Finance, 67, 1219-1264. https://doi.org/10.1111/j.1540-6261.2012.01746.x

Pastor, L., \& Veronesi, P. (2013). Political uncertainty and risk premia. Journal of Financial Economics, 110, 520-545. https://doi.org/10.1016/j.jfineco.2013.08.007

Pesaran, M. H., Shin, Y., \& Smith, R. J. (2001). Bounds testing approaches to the analysis of level relationships. Journal of Applied Econometrics, 16(3), 289-326. https://doi.org/10.1002/jae.616

Pomogajko, K., \& Voigtlander, M. (2012). Co-movement of house price cycle - a factor analysis. International Journal of Housing Markets and Analysis, 5(4), 414-426. https://doi.org/10.1108/17538271211268583

Qi, Y., Roth, L., \& Wald, J. K. (2010). Political rights and the cost of debt. Journal of Financial Economics, 95(2), 202-226. https://doi.org/10.1016/j.jfineco.2009.10.004

Rahadi, R. A., Wiryono, S. K., Koesrindartoto, D. P., \& Syamwil, I. B. (2015). Factors influencing the price of housing in Indonesia. International Journal of Housing Market and Analysis, 8(2), 169-188. https://doi.org/10.1108/IJHMA-04-2014-0008

Terrones, M., \& Otrok, C. (2004). The global house price boom. IMF World Economic Outlook.

The Sun Daily, (2015). Construction costs have risen: Rehda. Retrieved from $\mathrm{http}: / / \mathrm{www} \cdot$ thesundaily.my/news/1551093

Thomas, M. A. (2010). What Do the World Governance Indicators Measure? European Journal of Development Research, 22, 31-54. https://doi.org/10.1057/ejdr.2009.32

Tsatsaronis, K., \& Zhu, H. (2004). What drives housing price dynamics: Cross country evidence. BIS Quarterly Review, 3, 65-78.

Zalieckaite, D., Snieska, V., Vasauskaite, J., \& Remeikiene, R. (2007). Price bubble in the Lithuania real estate market? Kaunas: Kaunas University of Technology.

\section{Copyrights}

Copyright for this article is retained by the author(s), with first publication rights granted to the journal.

This is an open-access article distributed under the terms and conditions of the Creative Commons Attribution license (http://creativecommons.org/licenses/by/4.0/). 